\title{
Perceived Success of Entrepreneurs in the Vaal Region of South Africa with Special Reference to Fashion Entrepreneurs
}

\author{
Prof. Kholeka Constance Moloi \\ Vaal University of Technology, Faculty of Human Sciences, \\ Vanderbijilpark, 1900, South Africa \\ Email: conniem@vut.ac.za \\ Mrs. Matseliso Alphoncina Nkhahle \\ Vaal University of Technology, Faculty of Human Sciences \\ Vanderbijilpark, 1900, South Africa \\ E-mail: tselinkhahle@wedbmail.co.za
}

Doi:10.5901/mjss.2014.v5n1p225

\begin{abstract}
The aim of this study is to investigate the perceived success of fashion entrepreneurs in the Vaal region of South Africa. With the advent of democracy in South Africa since 1994 and the ascendency to political power of the African National Congress (ANC), many transformations in the socio-political and economic spheres have taken place with a view to addressing the imbalances of the past inherited from the segregationist regime of the National Party (NP). Furthermore, the transformation agenda in the country has been directed at addressing issues of quality of life for all, equity in terms of education as well as access to health services, poverty eradication and unemployment. Consequently, with the intention of eradicating unemployment, a number of initiatives have been implemented. The research design for the study was a quantitative method of investigation, using a descriptive exploratory questionnaire to find information on the success of fashion entrepreneurs. The study found that most of the fashion entrepreneurs gained their sewing skills at universities (30.4 percent) while others learnt from their parents (21.6 percent). Some of the fashion entrepreneurs started their businesses only after completing a fashion course.
\end{abstract}

Keywords: Entrepreneurship, fashion entrepreneurs, Vaal region, economy, transformation

\section{Introduction}

With the advent of democracy in South Africa since 1994 and the ascendency to political power of the African National Congress (ANC), many transformations in the socio-political and economic spheres have taken place with a view to addressing the imbalances of the past inherited from the segregationist regime of the National Party (NP). Furthermore, the transformation agenda in the country has been directed at addressing issues of quality of life for all, equity in terms of education as well as access to health services, poverty eradication and unemployment. Arguably, unemployment has been and continues to be one of the major challenges facing South Africans, affecting particularly those people who come from under-privileged backgrounds (North 2002:24; Rogerson 2006). Consequently, with the intention of eradicating unemployment, a number of initiatives have been implemented. These initiatives include the upliftment, through entrepreneurial opportunities and relevant courses, of people who own small businesses. The focus on entrepreneurship is aimed at creating more jobs for unemployed South Africans (Kingdon \& Knight 2004:1). Moreover, entrepreneurs are said to be individuals who accept risks and who are innovative in terms of their business management skills, while displaying the personal traits of risk taking, creativity, ambition and other qualities involved in the provision of products and services to society (Littunen 2000:295; Marshall, Jackson, Stanley, Kefgen \& Touchie-Specht 2000:172; Turner 2005:264).

In the context of this article, fashion entrepreneurs are significant because of their impact on the growth of small businesses. Fashion entrepreneurs are categorised into various fashion-related professions such as freelancing, fashion photographers, graphic designers, fashion illustrators and pattern makers (Burke 2008:27). Within the context of the South African political economy, small businesses are viewed as entities that contribute to the government's gross domestic product (GDP) (Rogerson, 2000:687). Expanding this view, Merrett and Gruidi (2000: 426) assert that it is 
important to eradicate poverty because it negatively affects the country's growth and development (Rogerson 2005:35). To be able to contribute to job creation, entrepreneurs must be successful in terms of various factors such as their basic level of education, the skills they possess, industry experience as well as their potential to access finances for starting up their small businesses. The growth and profitability of the business is very important, not only for owners of small businesses but also for the economic development of the country in general (Smit 2000:04; Cronje, Du Toit \& Motlatla 2001:10; Burke 2008:12; Vallone 2008:16).

In the fashion sector, a person who starts a business (Hisrich \& Peters 2002:07) and possesses the abovementioned entrepreneurial personal traits, with particular emphasis on creativity, is called a fashion entrepreneur (Burke 2008:12). For the purpose of this study reported by this paper the focus will be on individuals that construct and sew clothes as well as on those who sew curtains (Toffoli 2007:58, 59). As indicated, the role of entrepreneurs is to make profit and to create jobs, particularly in communities which are less privileged, but also to contribute, as indicated above, to the country's economic development. The next section will illuminate the problem statement in light of this.

\section{Problem Statement}

A considerable amount of research which focuses on entrepreneurship, the entrepreneurial culture in South Africa and fashion entrepreneurship has been undertaken by researchers such as Van Wyk (2007), (Merrett \& Gruidi (2000), Deamer \& Earle (2004) and Vallone (2008), to name but a few. Examples of research conducted in the United States of America and South Africa regarding entrepreneurship include studies investigating the demographics and success factors of entrepreneurs (Merrett \& Gruidi 2000), their entrepreneurial traits (Deamer \& Earle 2004), the success and failure of apparel entrepreneurs (Vallone 2008) and small fashion owners and their businesses in the Vaal region (Van Wyk 2007). Success factors for fashion entrepreneurial businesses are extensively identified in the literature review, but research is silent about the extent to which these factors apply to fashion entrepreneurs.

The limited information on fashion entrepreneurs, particularly in the Vaal region, prompted the researchers to address this gap by undertaking this study. The authors are of the opinion that the study is important because it provides an angle on how fashion entrepreneurs can be successful despite limited financial resources. Furthermore, this study could contribute to a better understanding of entrepreneurship in the less explored Vaal region and could be of value to academics as well as fashion entrepreneurs in terms of useful information for future entrepreneurs interested in participating in the fashion or clothing sector. There is a great need in the Vaal region to focus studies on fashion entrepreneurs because of the level of poverty among communities who live in informal settlements (those settlements which are not in the statutory laws of the country) and in the black communities residing outside the more advanced suburbs. Previous studies undertaken by Honig (1998), Bruce and Holtz-Eakin (2001), Turner (2005), and Rogerson (2006) stipulate that the success of a business is measured in terms of its growth and sufficient structure to support the business.

\section{Aims of the Study}

The aims of this study are to:

- Investigate the perceived success of fashion entrepreneurs in the Vaal region of South Africa.

- Explore the challenges faced by entrepreneurs in starting up their businesses.

\section{Research Questions}

The research questions are stated as follows:

- What is the perceived success of fashion entrepreneurs in the Vaal region of South Africa?

- What challenges do entrepreneurs face in starting up their businesses?

\section{Literature Review}

The literature review focuses mainly on the factors that contribute towards the success of fashion entrepreneurs, their personal traits and the influence of their sources of inspiration. Several studies conducted on the success of entrepreneurs highlighted factors such as entrepreneurial traits, entrepreneurial skills and demographics (Vallone 2008:18; Kuratko 2009:31). These factors are predicted to correlate well with the client's satisfaction and trust, resulting 
in the success of an entrepreneurial business (Littunen 2000:295; Olson 2000:15).

In South Africa, the entrepreneurial landscape ranges from formal to informal businesses, some of which empower people by employing them (McDade \& Spring 2005:18). Formal businesses are classified as those businesses that are registered and pay tax, while informal businesses are referred to as unregulated and unregistered (McDade \& Spring 2005:19; Krauss, Frese \& Friedrich 2005:322-323). Most fashion entrepreneurs fall in the unregistered category (Moodley 2003:62). Informal businesses occupy 20 percent to 40 percent of all businesses in South Africa (Rogerson 2005:39) and are known to employ from one to ten employees (Honig 1998:372; Kaplan 2004:623). Unemployment in South Africa is one of the major problems (North 2002:24, Rogerson 2006). Therefore, South Africans can create jobs through entrepreneurship to overcome unemployment (Rankhumise \& Rugimbana 2010:3500).

There are various factors that contribute to the success of entrepreneurs, including the personal traits of the entrepreneurs, the objectives of the business, financial leverage, the location of the business, its employees, and business management strategies and skills (Gadenne 1998:38-39). Most of these factors that contribute to the success of entrepreneurs are investigated in this study with respect to their effect on the success of fashion entrepreneurs in South Africa and, more specifically, in the Vaal region. The constraints on the success of entrepreneurial businesses are also investigated.

\subsection{Entrepreneurship}

The meaning of entrepreneurship is becoming broader as research interest in this concept grows (Lin, Miao \& Nie 2012:494). For instance, Stokes and Wilson (2006:31) describe entrepreneurship as a process that involves individuals as well as the community and creates value both for those involved and for society. Entrepreneurship is also a process of creating a new business by devoting time and effort and looking forward to gaining profit in return (Stokes \& Wilson 2006:32) and to growth in the business (Nieman et al. 2003:9). To be a successful entrepreneur requires energy and passion in the creation and implementation of new ideas, as well as in finding creative solutions for problems. Entrepreneurs should have the fundamental skills, resources and vision to recognise an opportunity (Burns 2007:307; Kuratko 2009:05).

\subsection{The entrepreneurial culture in South Africa}

In developing countries in sub-Saharan Africa, entrepreneurship is practised based on factors such as age and kinship. This has inhibited entrepreneurship in African countries, including South Africa. People were denied the opportunity to develop entrepreneurial skills and build the confidence to run a business (Nieman et al. 2003:12). Today, however, Higher Education Institutions (HEls) assist in the development of entrepreneurship education (Co \& Mitchell 2006:348) and training (Henry et al. 2005:101). The aim of such training is to provide practical as well as theoretical help. Training and education also make possible the conversion from traditional employment to self-employment (Henry et al. 2005:102,103).

There are various non-profit programmes that assist in the educating and training of entrepreneurs in South Africa. These include Entrepreneurship Education Initiative (EEI), the Education with Enterprises Trust (EWET) and Junior Achievement (JA), (North 2002:25). The Small Enterprise Development Agency (SEDA) and Umsobomvu Youth Fund (UYF) also support entrepreneurs (Nieman et al. 2003:166). The JA is an example of the above programmes and offers experiential business skills programmes to youth. JA operates with the Centre for Developing Business of the University of the Witwatersrand together with other universities and private sectors to enhance skills development (North 2002:25). Higher learning institutions play a role here in educating learners and developing their entrepreneurial traits (Co \& Mitchell 2006:389).

To improve fashion entrepreneurship, high schools should be required to give academic support (Fatt 2001:74). According to Co and Mitchell (2006:354), universities in South Africa, in teaching entrepreneurship, devote 80 percent of class time to theory, while only 20 percent of the time is devoted to practical experience outside the classroom. This method of teaching needs to be changed because it reveals more about the teacher than the subject being taught. Entrepreneurial education should be supported academically as well as publicly. Moreover, funds should be obtained to support entrepreneur education (Dhliwayo 2008:334).

\subsection{Fashion and fashion entrepreneurs}


There are many definitions of the concept of fashion. Fashion is described in the Oxford English Dictionary (OED) as a current popular custom or style, especially in dress (OED 1989:441). Crane and Bovone (2006:321) argue that fashion is the product of individual decisions in different industries. According to Brannon (2005:15), fashion is a "style that is popular in the present or a set of trends that have been accepted by a wide audience". People want fashion rather than clothes, not to cover the naked body, but to cover the self-esteem. Craik (2009:2-3) views fashion as a cultural practice that prevails, or as the custom or style of dressing of a particular period. Fashion is perceived as emerging not only from the national and regional levels of the political sociology of the community, but is also considered to be a cyclical reconsideration of culture and society. For these reasons, fashion is an essential human creative skill that contributes to the social development of mankind. Images of important ancient civilisations and illustrations of the qualities of individual societies over the years are being shown as fashion (Azuma \& Fernie 2003:414-415).

Fashion entrepreneurs are people who focus on selling fashion-related products such as shoes, accessories, wedding gowns, matric farewell gowns and evening garments, as well as curtains and other attractive products in the field of fashion (Burke 2008:12). There are several reasons why South African fashion entrepreneurs set up fashion businesses. Firstly, they are ambitious of being financially independent; secondly, they want to contribute positively to the rebuilding of the South African identity; and thirdly, they want to preserve African culture and heritage (Rogerson 2006:228). However, for the purpose of this study, the focus is on fashion entrepreneurs who earn income by sewing garments as well as articles such as curtains and soft furnishings for interiors.

Generally, entrepreneurs are people who create new businesses by taking risks for the purpose of achieving profit and growth, as well as by identifying new opportunities (Smit 2000:4). Entrepreneurs are capable of confronting reality and thinking of ways to improve, and for them, action is a natural consequence of thought (Smit 2000:4; Scarborough \& Zimmerer 2003:4). Entrepreneurs' decisions on investment, production and employment influence not only the state of the economy but also the prosperity of the community as a whole (Cronje, Du Toit \& Motlatla 2001:5).

\section{Research Design and Methodology}

The research design for the study was a quantitative method of investigation, using a descriptive exploratory questionnaire to find information on the success of fashion entrepreneurs. The focus was on gathering demographic information about fashion entrepreneurs and general information regarding entrepreneurship. This was achieved by means of an interviewer-administered questionnaire so that the researcher could clarify certain questions if the respondents did not understand (Babbie \& Mouton 2001:80; Babbie 2010:274). The quantitative method was chosen because it satisfies the researcher's interest in and desire for better understanding of the phenomenon under investigation (Babbie \& Mouton 2001:80). It is objective and explains phenomena by collecting numerical data that are analysed using mathematically based methods (Creswell 2009:12). Moreover, it is also an economical method of data collection and the researcher is has a neutral approach to the study (Delport 2005:159). This method is consistent with the theories chosen for the study. Economic theories of entrepreneurship view the contribution of the entrepreneur to be the creator of new enterprise, clearly establishing an outcome-based approach to understanding new venture formation. However, the economics stream continues to be in need of effective operationalisation. For example, articles advocating economic theories of entrepreneurship often leave the empirical tests to future research. While economic theories have been useful in helping to identify what entrepreneurship is and when it occurs, they have been less beneficial in helping to explain the more micro questions of how and why (Mitchell 2004: 166).

\subsection{Study site}

The Vaal region, located in the Gauteng province in South Africa, was the geographical area for this study. This region is comprised of Vanderbijpark, surrounded by small townships such as Bophelong, Bedworth Park, Sharpeville, Boipatong, and Tshepiso. These areas were chosen because they were convenient for the researcher in terms of investigating the factors contributing to the perceived success of local fashion entrepreneurs.

\subsection{Study population and sampling procedure}

Fashion entrepreneurs in the Vaal region who can construct and sew clothes and curtains made up the sample of this study. A non-probability sampling technique was used because the sample for this study was difficult to find, and time, as well as money, was a constraint. The 208 respondents $(n=208)$ for this study were selected using non-probability 
convenience snowball sampling. Convenience sampling was used because the respondents were selected based on their convenience and availability, as suggested by Creswell (2009:149). Snowball sampling was used because the members of a specific population were difficult to locate (Babbie \& Mouton 2001:167). Snowball sampling involves approaching single individuals involved in the field under investigation with a request to refer the researcher to other similar persons who may take part in the study (Strydom 2005:203).

\subsection{Development of the questionnaire}

A structured (closed-ended) questionnaire was compiled to collect the required data. The advantages of using closed questions in a questionnaire are that closed questions allow for a set of responses from which the respondents have to choose responses. Data collected by the administration of this type of questions are easier to analyse (Babbie \& Mouton 2001:233, 234, Maree \& Pietersen 2007:161). The questionnaire consisted of different sections and was compiled according to the research objectives of this paper. A nominal scale was used for section A of the questionnaire. In ordinal scales, data were grouped into classes in a form of Likert-type scale. For example, questions required responses indicating levels of agreement ranging from strongly disagree $=1$, disagree $=2$ or agree $=3$, to strongly agree $=4$, which were adjusted according to the suggestion of Maree \& Pietersen (2007:148). The questionnaire for this paper comprised questions on demographic information and general information regarding entrepreneurship and fashion entrepreneurial businesses.

\subsection{Pre-testing of the questionnaire}

For this paper, a measuring instrument was piloted among ten respondents who were not included in the main study. Firstly, before it was given to the ten fashion entrepreneurs, pre-testing of the questionnaire took place among five subject experts to ensure validity as well as to clarify the wording of the questionnaire and to indicate possible omissions. Secondly, the questionnaire was given to ten fashion entrepreneurs who did not take part in the main research study, who completed the questionnaire on two consecutive occasions, one week apart, to ensure reliability. The other reason for pre-testing was to make sure that the respondents understood all the questions and that other aspects of the questionnaire were clear. Pre-testing was done also in order to ensure that the questionnaire met the researcher's expectations in terms of the information that was obtained, as suggested by Aaker, Kumar and Day (2004:329).

\subsection{Validity}

Content validity and judgment by a panel of experts were measured for the purpose of this paper. Each expert was given the questionnaire to complete individually and to judge how well it met the objectives of this paper.

\subsection{Reliability}

For this study, test-retest reliability and interrater reliability were used to estimate reliability. The measuring instrument was given to ten fashion entrepreneurs for two consecutive weeks to record their responses. The two responses yielded the same results when estimated using the computer program Statistical Package for Social Sciences (SPSS 17.0 software).

\subsection{Population}

The population of this study was difficult to locate as there was no list of all the fashion entrepreneurs who construct and sew clothes as well as those who sew curtains in the Vaal region. Eighteen fashion entrepreneurs $(n=18)$ in the Vaal region, who were registered with the Vaal Wed organisation (which is the organisation for fashion entrepreneurs who sew wedding gowns in the Vaal region), as well as forty-four fashion entrepreneurs ( $n=44)$ who had taken part in a study by Van Wyk (2007), were the first people to be contacted to find out if they were willing to take part in the study. Those who were willing to participate were asked to mention other fashion entrepreneurs they knew of who would be willing to participate in the study, as stipulated by Babbie (2010:193). 


\subsection{Data collection}

Pre-testing was done using a judgement by a panel of experts to validate the questionnaire and to determine the validity of the questions used. The pilot study was done with 10 fashion entrepreneurs not taking part in the main study during May 2011 to determine test-retest reliability. The main study was done from June 2011 to August 2011. The researcher administered all the questionnaires.

\subsection{Data analysis}

Data were captured by the researcher and validated by a different person. Any differences were then checked against the original data and corrected. The SPSS (Statistical Package for Social Sciences) version 17.0 was used to analyse the data. Data were analysed to yield descriptive statistics. The data were analysed by means of frequency distribution, mean scores and standard deviations, Pearson's correlations as well as t-tests. The quantitative data were analysed in the numeric form of analysis using descriptive analysis. The analysis was conducted to identify mean scores, standard deviations and range scores for the variables and ranking order (Creswell 2009:152). In order to test the hypothesis, a ttest was also carried out to determine whether male and female fashion entrepreneurs have the same personal traits.

\section{Ethical Considerations}

Ethical considerations were adhered to in this study, which involved agreements between the researchers and the selected respondents (Babbie \& Mouton 2001:520). These agreements observed voluntary participation, as suggested by Coertze (1999:178), Creswell (2009:89) and Babbie (2010:64), which allowed respondents to contribute or not to contribute to the study voluntarily (Babbie \& Mouton 2001:521). The researchers kept in mind that no harm should be done to respondents (Creswell 2009:89; Babbie 2010:64). Questions relating to personal characteristics of the fashion entrepreneurs that would be humiliating or make participants feel uncomfortable, such as their bank statements, were also avoided, (Babbie \& Mouton 2001:522; Creswell 2009:89; Babbie 2010:66). The interests of the respondents taking part in the study were protected by not revealing their identities (Babbie \& Mouton 2001:523; Maree \& Van der Westhuizen 2007:42). The anonymity and confidentiality of the results and findings of the study also protected the respondents' identities, as suggested by Maree \& Van der Westhuizen (2007:42). Moreover, the authors believe that misleading the respondents is unethical. The true purpose of conducting the research was communicated to the respondents (Babbie \& Mouton 2001:525 -526; Creswell 2009:89; Babbie 2010:67-70).

\section{Findings and Discussion}

The researchers found that, with regard to demographic information, most of the participants were female (69.4 percent). Males constituted only one third (30.6 percent) of the total number of respondents. The respondents for this paper were mainly black Africans (86.6 percent) while fewer were Caucasian (6.9 percent), Coloured (4.5 percent) and Asian (2 percent). The age profile of the fashion entrepreneurs ranged from $<30$ years (34.6 percent), 30-39 years (35.1 percent), 40-49 years (26 percent); 4.3 percent were $50+$ years old. The majority of fashion entrepreneurs in this study ranged in age from 30 to 39. This age group represents people who are and who have been in the fashion industry, who have a keen interest in fashion and want to start their own fashion business. The results indicate that 89.5 percent of the respondents obtained a qualification after school. The questions do not indicate fashion-related qualifications only but all qualifications. More than 32.9 percent have grade 12, 26.1 percent have a certificate, 22.7 percent have a National Diploma, 7.2 percent have a Bachelor of Technology degree (BTech), and 0.5 percent have a Master's degree.

The study also shows that around 56.5 percent of the respondents acquired their highest qualification at a tertiary institution and shows that at least 39.4 percent gained their sewing skills at tertiary institutions. According to McRobbie (2002:57), many fashion graduates had been looking for jobs in the fashion design industries but could not obtain employment, which was why becoming a fashion entrepreneur was a suitable option for them. Table 4.2 further shows that at least 21.6 percent learnt sewing skills from their family members. Sewing skills were gained through short courses by 11.1 percent of the respondents while 11.5 percent learnt their skills at school. Some of the respondents (8.7 percent) gained their sewing skills at work while others (7.7 percent) gained them from government training or workshops. Van Wyk (2007:99) has suggested that the government of South Africa should encourage entrepreneurship by providing people with more training opportunities to enhance skills development in fashion. Most of the respondents (35.3 percent) 
started their businesses after studying a fashion design course. Only one percent of the respondents bought an existing business, and more than 12 percent started businesses after working in the field of fashion. At least 32.4 percent of the respondents started businesses after having an idea to start a fashion business. According to Burke (2008:30), children are more likely to be entrepreneurs if their parents were entrepreneurs too. In this study, 16.9 percent of the respondents inherited family businesses. Most fashion entrepreneurs (35.3 percent) had a fashion background before casting themselves into the opening of fashion businesses. Unfortunately South Africans do not have an entrepreneurial culture (Nieman et al. 2003:11, 12). The fashion entrepreneurs were aware of marketing tools and they applied the different methods of advertising in varying degrees in their businesses so that their products would be made known to the public, as suggested by Lamb et al. (2004:316,322). However, word-of-mouth advertising was used more often than not.

The study shows that 33.7 percent of the respondents made use of a financial plan, while 30.8 percent made use of mentors in their businesses. At least 26 percent used a financial advisor and 21.6 percent had a marketing plan. It is worth noting, however that far more than half of the respondents did not use any of these business planning aids. Failing to make use of all the components of the business plan such as a financial plan and a marketing plan could lead to the business not being successful (Marx et al. 1998:752, 753; Cronje et al. 2001:308; Burke 2008:53). The fashion businesses participating in this study employed fewer than 10 employees, while 50 percent had no employees. At least 14 percent of the respondents could afford to employ two employees while only 2 percent could afford to employ ten employees. Turner (2005:267) noted that the number of employees in an entrepreneurial business normally varies from one to ten. However, when the business becomes successful, the owner tends to employ more workers (Rogerson 2000:689). Most of the respondents who had employees employed seamstresses (43.8 percent), followed by 38.5 percent who employed cleaners. According to Vallone (2008:33), fashion entrepreneurs should ask for advice from professionals such as marketing advisors, financial accountants and other professionals within the fashion design field. However, only 11.1 percent of the respondents in this study had a marketing advisor. A large number of fashion entrepreneurs employed more seamstresses and a cleaner. It could be argued that the cleaners were actually employed to clean the house.

The study shows that technology has made it easier for fashion entrepreneurs to use equipment which makes work easier and faster (Burke 2008:101; Ma 2008:21). The results indicate that the majority of the respondents (90.9 percent) had an electrical domestic iron, which is cheaper than the industrial one. A large number of the respondents (83.2 percent) had a domestic sewing machine while 70.2 percent had domestic overlockers (sewing machine). About 48.1 percent of the respondents had industrial sewing machines which work faster than domestic sewing machines and are capable of high-quality stitching, thereby increasing the effectiveness of the fashion entrepreneur. Some of the sewing equipment such as the cover stitch machine, industrial overlocker, industrial iron, domestic press, industrial press and industrial fabric are relatively expensive.

Furthermore, it was found that about 81.3 percent of the respondents made alterations to garments. Seventy percent of the respondents' businesses manufactured traditional wear, while evening garments were manufactured by at least 53.8 percent of the respondents. At least 47.1 percent of the respondents did work related to items for interiors, which includes the construction of certain articles. The results show that there is a good market for matric farewell garments (53.4 percent), evening garments (53.8 percent) and wedding garments (48.1 percent).

Concerning the technological tools used in fashion entrepreneurship, an industrial sewing machine was often/almost always used in the respondents' businesses (47.6 percent). About 29.8 percent of the respondents' businesses often/almost always used a computer for business purposes, with a mean score of 2.0. A computerised sewing machine (1.9 percent) was often/almost always used in the businesses. Computerised sewing machines constituted a mean of 0.5 . Advances in technology have made it easier for fashion designers to use technological equipment in their businesses (Burke 2008:114). But this study found that only a few fashion entrepreneurs made use of technological equipment such as computers (ranking order 3 ) and computerised sewing machines (ranking order 4). It could be that special training on how to use the equipment is needed and is very expensive. Moreover, such technologically advanced equipment can be expensive. Lack of money to buy the equipment as well as lack of specific skills needed to use it might be the reason.

The researchers also found that about 86.1 percent of the respondents claim to often/very often/almost always keep records of their expenditure and profit, with a mean score of 4.2. About 67.8 percent often/very often/almost always priced their products according to a set price list with a mean score of 3.5. The fact that the respondents were able to keep records of their expenditure (86.1 percent) indicates that these fashion entrepreneurs possessed financial skills. These results contradict those of Honig (1998:373) and Turner (2005:266), who noted that the owners of the entrepreneurial businesses are not able to separate household transactions from the business transactions. These 
results might have been influenced by the level of education of the majority of these respondents. The most popular sources of financial assistance during business start-up were the personal savings of the respondents ( 87.5 percent) and money borrowed from parents (43.8 percent). These results are similar to the findings of Ligthelm (2004:48) and Burke (2008:64). Lack of financial support is widely viewed as an obstacle among fashion entrepreneurs (Ligthelm 2004:48). It is indicated in the study that only 7.7 percent of the businesses were subsidised by the government, while those with loans from banks constituted only 5.3 percent. From these results it is clear that the main source of finance for starting a fashion business in the Vaal region is the personal savings of the fashion entrepreneur.

Finally, the study found that the fashion entrepreneurs rated their business performance as good (72.1 percent) with a mean of 2.3. About 49.5 percent of the respondents, with a mean score of 2.7, perceived their businesses success as good. About 54.8 percent of the respondents believed that the number of sewing machines in the business was also a measure of the success of the business. 'How long the business has been operating' was seen as a success factor by 47.1 percent. These findings indicate that profit and the number of employees in the business are the best indicators of the perceived success of fashion entrepreneurship. The majority (79.3 percent) of the respondents perceived themselves as successful, while 18.3 percent thought they were not successful. About 2.4 percent of the respondents perceived their businesses as very successful.

\section{Conclusion}

In this study referred to in this paper the authors argued that, with the advent of democracy in South Africa since 1994 and the ascendency to political power of the African National Congress (ANC), many transformations in the socio-political and economic spheres took place with a view to addressing the imbalances of the past inherited from the segregationist regime of the National Party (NP). We discussed the transformation agenda in the country and showed that its intention has been to address the challenges inherited form the past segregationist regime through entrepreneurship and the enhancement of small businesses. The authors argued that the focus on entrepreneurship is aimed at creating more jobs for the unemployed among South Africans in order to improve their livelihoods and simultaneously contribute to the country's GDP. We argued that fashion entrepreneurs are significant because of their impact on the growth of small businesses within the country.

\section{References}

Aaker, D.A., Kumar, V. \& Day, G.S. 2004. Marketing research. (8th ed). New York: Wiley.

Azuma, N. \& Fernie, J. (2003). Fashion in the globalized world and the role of virtual networks in intrinsic fashion design. Journal of Fashion Marketing and Management, 7(4):413-427.

Babbie, E. \& Mouton, J. (2001). The practice of social research. Cape Town: Oxford University Press.

Babbie, E. (2010). The practice of social research. (12 ${ }^{\text {th }}$ ed.). Belmont, California: Wadsworth Cengage learning.

Brannon, E.L. (2005). Fashion forecasting. 2nded. New York: Fairchild.

Bruce, D. \& Holtz- Eakin, D. (2001). Who are entrepreneurs? Evidence from taxpayer data. Journal of Entrepreneurial Finance and Business Ventures, 1(1):1-10.

Burke, S. (2008). Fashion entrepreneur. starting your own fashion business. Ringwood: Burke Publishing.

Burns, P. (2007). Entrepreneurship and small business. $2^{\text {nd }}$ ed. New York: Palgrave Macmillan.

Co, J.M. \& Mitchell, B. (2006). Entrepreneurship in South Africa: a national survey. Education and Training, 48, 348-359.

Coertze, D.J. (1999). Research methodology: a hands-on approach to problem solving. Pretoria: Van Schaik.

Craik. J. 2009. Fashion: the key concepts. New York: Berg Publishers.

Crane, D. \& Bovone, L. (2006). Approaches to material culture: the sociology of fashion and clothing. Poetics, 34:319-333.

Creswell, J.W. (2009). Research design qualitative, quantitative and mixed methods approaches. $3^{\text {rd }}$ ed. Thousand Oaks, California: Sage Publications, Inc.

Cronje, G.J., Du Toit, G.S. \& Motlatla, M.D.C. (2001). Introduction to business management. Cape Town: Oxford University Press.

Deamer, I. \& Earle, L. 2004. Searching for entrepreneurship. Industrial and Commercial Training, 36(3):99-103.

Delport, C.S.L. 2005. Quantitative data collection methods. In De Vos, A.S., Strydom, H., Fouche, C.B. \& Delport C.S.L. Research at grass roots: for the social sciences and human services professions. 3rd ed. Pretoria: Van Schaik publishers. pp. 159-191.

Dhliwayo, S. 2008. Experiential learning in entrepreneurship education: a prospective model for South African tertiary institutions. Journal of Education and Training, 50, 329-340.

Fatt, J.P.T. (2001). Encouraging fashion entrepreneurship in Singapore. Journal of Marketing and Logistics, 13, 72-83.

Henry, C., Hill, F. \& Leitch, C. (2005). Entrepreneurship education and training: can entrepreneurship be taught? Part 1. Education and Training, 47, 98-111.

Hisrich, R.D. \& Peters, M. P. (2002). Entrepreneurship. (5thed.). New York: McGraw-Hill Irwin. 
Kaplan, D. (2004). Manufacturing in South Africa over the last decade: a review of industrial performance and policy. Development of Southern Africa, 24(4):623:644.

Kingdon, G. \& Knight, J. (2004). Unemployment in South Africa: a micro economic approach. [Online]. Available: $<$ http://www.csae.ox.ac.uk>. (August 28, 2010).

Krauss, S.I., Frese, M. \& Friedrich, C. (2005). Entrepreneurial orientation: a psychological model of success among Southern African small business owners. European Journal of Work and Organizational Psychology, 14, 315-344.

Kuratko, D.F. (2009). Introduction to entrepreneurship. (8th ed.). Australia; United Kingdom: South-Western.

Lamb, C.W., Hair, J.F., McDaniel, C., Boshoff, C. \& Terblanche, N.S. (2004). Marketing. Cape Town: Oxford University Press.

Liang, J. (2011). Entrepreneurship and demographics. Graduate school of business, Stanford University.

Ligthelm, A.A. 2004. Profile of informal microenterprises in the retail sector of South Africa. Southern African Business Review, 8, $39-52$.

Lin, S., Miao, Q. \& Nie, K. (2012). A case study on entrepreneurship for sustained innovation African Journal of Business Management, $6,493-450$.

Littunen, H. (2000). Entrepreneurship and the characteristics of the entrepreneurial personality. International Journal of Entrepreneurial Behavior and Research, 6, 295-309.

Ma, A.W.W.M. (2008). Computer supported collaborative learning and social, creativity: a case study of fashion design. Journal of Information, Technology and Organizations, 3:17-39.

Maree, K. \& Pietersen, J. (2007). Sampling. In Maree (Ed.), First steps in research. Pretoria: Van Schaik 172-180.

Maree, K. \& Van der Westhuizen, C. (2007). Planning a research proposal. In Maree (Ed.). First steps in research. Pretoria: Van Schaik. pp. 24-44.

Marshall, S.G., Jackson, H.O., Stanley, M.S., Kefgen, M. \& Touchie-Specht, P. (2000). Individuality in clothing selection and personal appearance. (5thed.). New Jersey: London: Prentice Hall.

Marx, S., Van Rooyen, D.C., Bosch, J.K. \& Reynders, H.J.J. (1998). Business management. (2nd Ed.). Pretoria: Van Schaik Publishers.

McDade, B.E. \& Spring, A. (2005). The new generation of African entrepreneurs: networking to change the climate for business and private sector-led development. Entrepreneurship and Regional Development, 2, 17-42.

McRobbie, A. (2002). Fashion culture: creative work, female individualization. Feminist Review, 71:52-62.

Merrett, C.D. \& Gruidi, J.J. (2000). Small business ownership Illinois: the effect of gender and location on entrepreneurial success. Professional Geographer, 52, 425-436.

Mitchell, B.C. (2004). Motives of entrepreneurs: a case study of South Africa. The Journal of Entrepreneurship, 13, 167-183.

North, E. (2002). A decade of entrepreneurship education in South Africa. South African Journal of Education, 22, 24-27.

OED (Oxford English Dictionary). (1989). Architecture. (4th ed.). Oxford: University Press.

Olson, D.E. (2000). The role of entrepreneurial personality characteristics on entry decisions in a simulated market. California State University at Bakersfield.

Rankhumise, E.M. \& Rugimbana, R.O. (2010). Micro enterprise owner perspectives on performance: insights from selected municipalities in Mpumalanga Province, South Africa. African Journal of Business Management, 4, 3500-3507.

Rogerson, C.M. (2000). Successful SMEs in South Africa: the case study of clothing producers in the Witwatersrand. Development Southern Africa, 17, 687-716.

Rogerson, C.M. (2005). SMME development in peripheral regions: manufacturing in Free State province, South Africa. Urban Forum, $16,35-54$.

Rogerson, C.M. (2006). Fashion and the growth of 'African' brands in South Africa. African Clothing \& Footwear Research, 1:1-63.

Scarborough, N.M. \& Zimmerer, T.W. (2003). Effective small business management: an entrepreneurial approach. Upper Saddle River, New Jersey: Prentice Hall.

Smit, L. (2000). Entrepreneurship business management. (5th ed.). Cape Town: CLS Publishers.

Strydom, H. (2005). Sampling and sampling methods. In DeVos, A.S., Strydom, H., Fouche, C.B. \& Delport, C.S.L. (Eds.), Research at grass roots: for the social sciences and human service professions. (3rd ed.). Pretoria: Van Schaik. pp. 192-203.

Toffoli, H.P. (2007). Rag trade fights back. Pursuit: Fashion Business and Lifestyle, 8:58-59.

Turner, S. (2005). Nascent market capitalism under question: interpretations of success among Makassar entrepreneurs. Cultural Studies, 96, 264-274.

Vallone, A.M. (2008). A study of the success and failure of apparel entrepreneurs. Auburn: Alabama University.

Van Wyk, A.W. (2007). Small fashion owners and their businesses in the Vaal region. MTech dissertation. Vaal University of Technology: Vanderbijlpark. 
